\title{
An early-onset recessive cerebellar disorder with distal amyotrophy and, in two patients, gross myoclonia: a probable ataxia telangiectasia variant
}

\author{
A.S. de Graaf ${ }^{a, *}$, G. de Jong ${ }^{\mathrm{b}}$, W.J. Kleijer ${ }^{\mathrm{c}}$ \\ ${ }^{a}$ Department of Medicine, Neurology Unit, Tygerberg Hospital and University of Stellenbosch Medical School, Parowvallei, P.O. Box 19063, \\ Tygerberg 7505, Republic of South Africa \\ ${ }^{\mathrm{b}}$ Department of Obstetrics and Gynaecology, Human Genetics Unit, University of Stellenbosch Medical School, Parowvallei, Republic of South Africa \\ ${ }^{\mathrm{c}}$ Clinical Genetics Department, Erasmus University, Rotterdam, The Netherlands
}

Received 11 April 1994; revised 16 August 1994; accepted 19 August 1994

\begin{abstract}
We report a family of 4 siblings from a non-consanguineous marriage, presenting with an early onset recessive cerebellar ataxia and progressive distal limb wasting. Ocular or other telangiectasias were absent. There were neither frequent infections nor immunodeficiencies. The two youngest patients exhibited an incapacitating myoclonus which abated markedly after 20 years. Late onset diabetes was demonstrated in 3 patients. Hypogonadism was not a feature and there was a prolonged survival in the 4 patients. The oldest sibling died of a pancreatic adenocarcinoma. $\alpha$-Fetoprotein was elevated with normal carcinoembryonic antigen values in three patients. Cytogenetic analysis and radioresistant DNA synthesis was compatible with the diagnosis of ataxia-telangiectasia. This family probably represents a rare variant of ataxia-telangiectasia.
\end{abstract}

Keywords: Ataxia-telangiectasia; Chromosome instability; DNA replication

\section{Introduction}

Ataxia-telangiectasia (AT) is an autosomal recessive multisystem disorder with a variable clinical expression. In the original descriptions onset of cerebellar ataxia in infancy and ocular telangiectasia were considered to be distinctive features [1-3]. Other important clinical and laboratory markers such as recurrent sinopulmonary infections, immunodeficiency, impaired organ maturation, $\mathrm{X}$-ray hypersensitivity and a high incidence of malignancy were discussed by Waldmann et al. [4]. More recently Sedgwick and Boder [5] reviewed the various aspects of this disorder. Increased $\alpha$-fetoprotein and carcinoembryonic antigen have been recognized as important biochemical hallinarks [6,7]. Cytogenetic analysis, as reviewed by Kojis et al. [8], has revealed highly non-random chromosomal breakage in T-lymphocytes,

*Corresponding author. mainly involving chromosomes 7 and 14 , with inversions and translocations and, in some cases, telomeric fusions.

Another characteristic feature of AT is radioresistant DNA synthesis after ionizing radiation [9], but this is also true for the Nijmegen Breakage Syndrome $[10,11]$.

We present a family of 4 siblings with several unusual features compared with the classical descriptions of AT and suggest that these patients represent a probable variant of this disorder. Cytogenetic analysis and DNA resistant synthesis after irradiation as diagnostic procedures in such cases is recommended.

\section{Family history}

The 4 patients were the children of non-consanguineous parents of mixed ancestry. Patient 1 was the first child, patient 2 was the 11 th, patient 3 the 12 th and patient 4 the 14th and last child. Three other children had died at an early stage of their lives of apparently unrelated causes. Both parents and all living siblings were 
clinically and neurophysiologically investigated. No abnormalities were detected in the non-affected. Epilepsy did not occur in the family. The pregnancies and postnatal periods of the 4 patients had been uneventful. None of them smoked or used alcohol and they had not been exposed to drugs or other toxic substances. They were not known to be allergic to environmental or food items. The father died of a prostatic adenocarcinoma with metastases at the age of 75 years. Recently the mother died of a not further defined metastatic carcinoma at the age of 74 years.

\section{Case history}

\section{Patient 1 (female, born 1940)}

The time of onset of her symptoms and signs was difficult to ascertain accurately. She walked at 3 years of age, but her gait was apparently never entirely normal and she became increasingly ataxic. Distal limb wasting was noted before she was 10 years old. When first seen in 1978 she was cooperative and mentally slightly subnormal. Fundi and auditory functions were unremarkable. There was a slow initiation of both horizontal voluntary and involuntary eye movements, poorly sustained horizontal eye movements and a vertical gaze paralysis. Her speech was explosive and severely dysarthric. Tongue movements were slow. Gross cerebellar ataxia could be demonstrated in the trunk, upper and lower limbs, although more in the upper limbs, than in the lower ones. No tendon jerks could be elicited. Light touch and pinprick sensations were decreased below the knees, vibration and position sense were diminished in the toes. When she kept her arms in an outstretched position choreoathetotic movements in her hands and fingers were noted. Marked distal wasting in upper and lower limbs was present. The intrinsic foot muscles were fibrosed. Minimal ankle flexion could be performed. Strength in the intrinsic hand and foot muscles ranged from $0 / 5$ to $2 / 5$. She was wheelchair-bound when she was 32 years old and bedridden at the age of 46 years. Her previously normal fasting glucose levels had slightly risen during her last 2 years. She died of a pancreatic adenocarcinoma at the age of 50 years. Autopsy could not be performed.

\section{Patient 2 (female, born 1956)}

According to her mother nothing abnormal was noted until she was 10 years old. Then she developed an unsteady gait soon followed by clumsy handwriting and weakness in her legs. Her speech became dysarthric somewhat later. She could not pass primary school because of her handicaps. When first examined in 1978, her IQ was found to be slightly subnormal. Ocular fundi and auditory functions were normal. Eye movements were characterized by slow initiation and many saccadic movements when looking to the right and left, vertical eye movements were normal, there was no eye muscle paresis. Tongue movements were slow. Her speech was severely dysarthric with a scanning component. Marked cerebellar ataxia was seen in upper and lower limbs, more so in the former. Moderate wasting in lower leg and foot muscles was demonstrated. Tendon reflexes and sensation were normal, plantar responses flexor. She walked with a high-stepping and broad-based gait. Over the ensuing years wasting of the distal parts of her lower limbs markedly increased, and distal wasting in her upper limbs appeared. Ankle jerks could no longer be elicited. Sensation remained normal. Outstretched upper limbs provoked athetoid movements and mild myoclonic jerks in her fingers. She was able to walk unsupported for only a few steps. Non-insulin dependent diabetes mellitus developed over the last few years.

\section{Patient 3 (male, born 1957)}

This patient's early development was reported to be normal. He could run until he was 10 years old. Then his gait was noted to be unsteady, his speech deteriorated, became indistinct and explosive and clumsiness in his fingers began to interfere with his writing. He also became aware of weakness in his legs. At the age of 14 years gross myoclonic jerks appeared, seriously upsetting his balance and preventing him from walking unsupported. At 19 years of age he was wheelchair-bound.

The first clinical investigation, in 1978, revealed a cooperative young man of slightly subnormal intelligence. Fundi and auditory functions were normal. Initiation of lateral eye movements was slow and many saccadic movements were seen when lateral gaze was attempted. Passive head rotation did not provoke contralateral eye movements and there was no excessive blinking. Vertical eye movements were unaffected. Severe ataxia and dysmetria were apparent on cerebellar testing, more obvious in the upper than in the lower limbs. Truncal ataxia was difficult to assess on account of massive myoclonic jerks which threw him into the pillow or to the floor. Neck, trunk and shoulder muscles were mainly involved. His head turned to the right when he was jerking. Concurrent with these movements, tonic wrist flexion with hyperextension of thumb and index fingers was noted. Emotion, auditory and tactile stimuli precipitated the myoclonus.

Tendon jerks could be elicited, except at the ankles. Plantar responses were flexor. There was a decreased perception of vibration below the ankles. The other sensory modalities were normal. Marked distal wasting in upper and lower limbs and conspicuous fasciculations were noted in the affected muscles.

Over the following 15 years cerebellar functions slowly deteriorated. Distal wasting in upper and lower limbs increased. Strength in the intrinsic hand and foot muscles ranged between $0 / 5$ and $2 / 5$. A marked decrease in intensity and frequency of his myoclonic jerks had occurred 
during the last two years of routine follow-up. His fasting glucose levels had exceeded normal values during these years.

\section{Patient 4 (male, born 1962)}

This patient was well until his first symptoms appeared at the age of 7 years, comprising unsteadiness of gait, an explosive and scanning speech, clumsy handwriting and weakness in his legs. At the age of 10 , coarse jerks, very similar to those observed in his brother appeared and he was bedridden when he was 15 years old.

Initial neurological examination in 1978 was similar to that in his brother, including the abnormalities of the eye movements. Further clinical examinations and routine investigations were not essentially different from those of his brother. It is noteworthy that the coarse myoclonic jerks decreased markedly during the last year similar to those in his brother.

Table 1

Clinical features of ataxia-telangiectasia as described by Sedgwick and Boder [5] compared with those in the present family

\begin{tabular}{|c|c|c|}
\hline & $\begin{array}{l}\text { Sedgvick and } \\
\text { Boder [5] }\end{array}$ & Present family \\
\hline \multicolumn{3}{|l|}{ Neurological } \\
\hline $\begin{array}{l}\text { Onset of cerebellar } \\
\text { ataxia }\end{array}$ & $\begin{array}{l}\text { infancy or } \\
\text { childtood }\end{array}$ & $\begin{array}{l}\text { end of first decade in } \\
3 \text { subjects, } 1 \text { in infancy }\end{array}$ \\
\hline Course & progressive & progressive \\
\hline Speech & dysarthric & dysarthric \\
\hline Choreoathetosis & variable & mild \\
\hline Myoclonus & occasional & $\begin{array}{l}\text { massive in } 2 \text { patients, } \\
\text { abating after } 20 \text { years }\end{array}$ \\
\hline \multicolumn{3}{|l|}{$\begin{array}{l}\text { Progressive neuro- } \\
\text { muscular }\end{array}$} \\
\hline changes & late stages & early stages \\
\hline Deep reflexes & $\begin{array}{l}\text { diminished or } \\
\text { absent: }\end{array}$ & $\begin{array}{l}\text { present, except at } \\
\text { ankles }\end{array}$ \\
\hline $\begin{array}{l}\text { Deep and super- } \\
\text { ficial sensation }\end{array}$ & $\begin{array}{l}\text { intact, diminished } \\
\text { in late stage }\end{array}$ & mild \\
\hline $\begin{array}{l}\text { Ocular abnorm- } \\
\text { alities }\end{array}$ & apraxia and other & apraxia and other \\
\hline Drooling & frequent & absent \\
\hline $\begin{array}{l}\text { Cognitive } \\
\text { development }\end{array}$ & arrested & arrested \\
\hline Equable disposition & characteristic & characteristic \\
\hline \multicolumn{3}{|l|}{ Non-neurological } \\
\hline $\begin{array}{l}\text { Telangiectasia } \\
\text { (ocular and other) }\end{array}$ & characteristic & absent \\
\hline $\begin{array}{l}\text { Sinopulmonary } \\
\text { infections }\end{array}$ & frequent & exceptional \\
\hline Progeric changes & frequent & absent \\
\hline Hypogonadism & frequent & absent \\
\hline $\begin{array}{l}\text { Retardation of } \\
\text { somatic growth }\end{array}$ & frequent & absent \\
\hline Late onset diabetes & frequent & in 3 patients \\
\hline Neoplasms & frequent & $\begin{array}{l}\text { in oldest patient } \\
\text { at age } 50 \mathrm{yrs}\end{array}$ \\
\hline $\begin{array}{l}\text { Wheelchair-bound } \\
\text { Survival }\end{array}$ & $\begin{array}{l}10-15 \text { years } \\
\text { usually less than } \\
2 \text { decades }\end{array}$ & $\begin{array}{l}3 \mathrm{~d} \text { decade in } 2 \text { patients } \\
\text { prolonged }\end{array}$ \\
\hline
\end{tabular}

Table 2

Serum Ig levels in the 3 youngest patients and their parents

\begin{tabular}{|c|c|c|c|c|c|c|}
\hline & $\begin{array}{l}\text { Patient } \\
2\end{array}$ & $\begin{array}{l}\text { Patient } \\
3\end{array}$ & $\begin{array}{l}\text { Patient } \\
4\end{array}$ & Mother & Father & Normal range \\
\hline $\operatorname{IgA} \mathrm{g} / 1$ & 7.23 & 3.54 & 5.62 & 3.63 & 8.96 & $0.80-3.00 \mathrm{~g} / 1$ \\
\hline $\lg G \mathrm{~g} / 1$ & 20.90 & 21.00 & 18.00 & 25.10 & 17.60 & $7.70-15.10 \mathrm{~g} / 1$ \\
\hline $\operatorname{IgM} \mathrm{g} / 1$ & 3.06 & 3.23 & 2.14 & 2.68 & 0.78 & $0.65-2.10 \mathrm{~g} / 1$ \\
\hline $\operatorname{IgE} g / l$ & 243.00 & 93.0 & 700.00 & 233.00 & 321.00 & $<116.0 \mathrm{~g} / \mathrm{l}$ \\
\hline
\end{tabular}

Table 1 shows the similarities and differences of the clinical features of AT, as described by Sedgwick and Boder [5], and the present family.

\section{Laboratory investigations}

Routine laboratory examinations of blood, urine and cerebrospinal fluid were normal, except for a slightly raised alkaline phosphatase level in patient 2 . A diagnosis of diabetes mellitus was made in patients 1,2 and 3 at the age of 48,34 and 36 years respectively. Fasting cholesterol values in the 3 oldest patients were raised with unfavourable HDL/total cholesterol and HDL/ LDL ratios.

The following screening involved the 3 youngest patients only: arylsulphatase A, $\beta$-galactosidase and hexosaminidase $A$ in serum. Thin-layer chromatography of urinary oligosaccharides showed no abnormal bands, and the absence of sialylated oligosaccharides and free sialic acid excluded the sialidoses and free sialic acid storage disorders. Urine amino acid profiles were normal in all 3 siblings.

Immunological evaluation comprising lymphocyte transformation to phytohaemagglutinin (PHA) mitogen, white blood and lymphocyte counts, cell subsets, comprising total $\mathrm{T}$ and $\mathrm{B}$ cells, $\mathrm{T}$ helper and $\mathrm{T}$ suppressor cells elicited normal values in the 3 youngest patients and their parents. Serum immunoglobulins are shown in Table 2.

The $\alpha$-fetoprotein serum values in patients 2,3 , and 4 were 737,448 and $599 \mathrm{ng} / \mathrm{ml}$, respectively. The carcinoembryonic antigen levels in these patients were 8 , 6 and $9 \mathrm{ng} / \mathrm{ml}$, respectively (normal range for the two oncofetal antigens is $\leq 10 \mathrm{ng} / \mathrm{ml}$ ). These values for both parents were normal.

\section{Other diagnostic procedures}

Computerized tomography (CT) and Magnetic resonance (MR) scans revealed a moderate cerebellar atrophy, mainly affecting the vermis, in the 3 youngest siblings. A severe cerebellar atrophy was most conspicuous in the vermis of the oldest patient, only in this patient some brainstem involvement was visible. The supratentorial areas of all siblings were normal. 
Ultrasonic studies of the abdomen and the pelvis as well as scintigraphy of liver and spleen were normal in each of the 3 youngest patients.

Electrocardiographic investigations in patient 2 showed signs in keeping with anterolateral and inferior ischemia. Echocardiographic studies in the two youngest subjects disclosed endocardial thickening of both right and left ventricular aspects of the inter-ventricular septum, possibly fibro-elastosis.

\section{Neurophysiological studies}

Electroencephalographic recording was normal in each of the 4 patients. Whole night sleep records in the two youngest siblings were also normal. Electromyographic sampling in upper and lower limbs revealed numerous denervation potentials and fasciculations as well as a marked reduction in the number of motor unit potentials on maximum effort. Motor nerve conduction studies disclosed a moderate reduction in conduction velocities (CV) in the upper limbs and there was no response in the lower limbs of the 3 oldest sibs. Amplitudes were markedly reduced. Sensory CVs in median and sural nerves were either normal or slightly diminished, the amplitudes were reduced. A deterioration in both motor and sensory CVs was recorded over the years.

Somatosensory evoked potentials, recorded from stimulation at wrist and ankle were normal. Brainstem auditory evoked potentials were also normal. Visual evoked potentials could not be reliably recorded on account of extrapyramidal movements, except in patient 2 in whom they were normal. Audiograms of the two youngest brothers were unremarkable.

\section{Biopsies}

A sural nerve biopsy performed on the youngest patient showed a $50 \%$ reduction of large myelinated fibres when compared with a normal age-matched control. Small myelinated and unmyelinated fibres were normal in structure and number. There was no 'onion bulb' formation and no evidence of demyelination, active axonal degeneration, or sprouting and cluster formation. Schwann cell proliferation was not apparent.

The transverse axonal area was decreased relative to the myelin sheath spiral. The areas were $50 \%$ less than for the age-matched control. There were no cytoplasmic inclusions in the Schwann cells suggestive of metabolic disorders.

A muscle biopsy of patient 4 showed neurogenic atrophy of his gastrocnemius muscle.

\section{Cytogenetic studies}

Cytogenetic analysis was done on lymphocytes of the 3 youngest affected siblings as well as the mother. The lymphocytes were stimulated with phytohemagglutinin and cultured for $96 \mathrm{~h}$. A total number of 100 trypsin-
Giemsa banded metaphase spreads were analysed from patients 2 and 3 , while only 80 metaphases of patient 4 were available for analysis. 50 metaphases of the mother were analysed.

Table 3 shows the rearrangements encountered. No rearrangements were found in the chromosomes of the mother. Telomeric fusions were absent. Chromosome breakages occurred in $10 \%$ of metaphase spreads of patients 2 and 4 , with $5 \%$ in patient 3 and $6 \%$ in the mother. Aneuploidy of metaphases with loss of a single chromosome (different in each metaphase) was found in 3 cells of patient 2. Two additional cells showed a 45,XO complement. Random chromosome loss was found in 2 metaphases of patients 3 and 4 out of 80 metaphases of patient 4 . The mother had 6 metaphases $(12 \%)$ showing a loss of one $\mathrm{X}$ chromosome $(45, \mathrm{XO})$, with random loss of 1 chromosome in 3 other metaphase spreads and additional chromosomes in 3 metaphases (the extra chromosomes were 7,17 and 15 and 19).

\section{Radioresistant DNA synthesis}

Inhibition of DNA synthesis after gamma irradiation of cultured skin fibroblasts was assayed as described by Jaspers et al. [11]. Cell cultures in dishes were prelabelled with $\left[{ }^{14} \mathrm{C}\right]$ thymidine, exposed to various doses of gamma rays $\left({ }^{137} \mathrm{Cs}\right)$, and then incubated for $4 \mathrm{~h}$ in medium with $\left[{ }^{3} \mathrm{H}\right]$ thymidine. The ratio of ${ }^{3} \mathrm{H}$ and ${ }^{14} \mathrm{C}$ incorporation was established by dual label liquid scintillation counting and the DNA synthesis rate was expressed as a percentage of the rate in unirradiated cells.

Fig. 1 shows the results for the cell strains of the three patients (patient 2, 3 and 4), one known AT patient and a control. In normal control cells the DNA synthesis rate after $10-20 \mathrm{~Gy}$ is generally reduced to $25-40 \%$ of the level in the same cell strain without irradiation. By con-

Table 3

Rearrangements of chromosomes in lymphocyte cultures of 3 affected siblings

\begin{tabular}{|c|c|c|c|}
\hline & \multicolumn{3}{|c|}{ Number/patient } \\
\hline & Patient 2 & Patient 3 & Patient 4 \\
\hline $\mathrm{t}(7 ; 14)(\mathrm{pl} 3 ; \mathrm{q} 11)$ & 5 & 1 & 1 \\
\hline $\mathrm{t}(7 ; 14)(\mathrm{q} 34 ; \mathrm{q} 32)$ & 2 & & \\
\hline $\mathrm{t}(7 ; 14)(\mathrm{q} 34 ; \mathrm{q} 11.2)$ & & & 5 \\
\hline$t(7 ; 9)(p 13 ; q 22)$ & 1 & & \\
\hline $\mathrm{t}(7 ; 7)(\mathrm{p} 13 ; \mathrm{q} 22)$ & 1 & & 1 \\
\hline $\operatorname{inv}(7)(p 13 ; q 34)$ & 1 & 5 & 3 \\
\hline $\mathrm{t}(6 ; 9)(\mathrm{q} 23 ; \mathrm{q} 22)$ & & 1 & \\
\hline $\mathrm{t}(6 ; 16)(\mathrm{q} 22 ; \mathrm{q} 21)$ & & 2 & \\
\hline $\mathrm{t}(2 ; 4)(\mathrm{p} 25.1 ; \mathrm{q} 13.1)$ & & & 1 \\
\hline $46, X X, 13 q+$ & & & \\
\hline $46, X Y, 10 p^{+}$ & & 1 & \\
\hline $46, \mathrm{XY}, \operatorname{del}(11)(\mathrm{p} 11.2 \mathrm{p} 12)$ & & 5 & \\
\hline Total of cells analysed & 100 & 100 & 80 \\
\hline
\end{tabular}




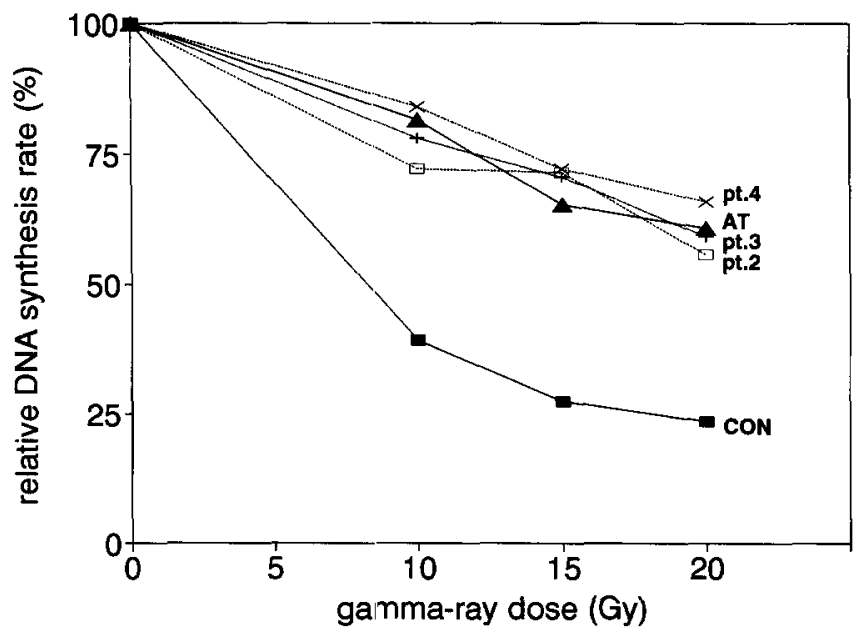

Fig. 1. Inhibition of DNA synthesis after gamma irradiation of cultured skin fibroblasts of patients $2(\mathrm{I}), 3(+)$ and $4(\times)$, a patient with ataxia telangiectasia ( $\mathbf{\Lambda})$ and a normal control individual ( $\mathbf{\square})$.

trast the DNA synthesis rate in AT cells remains at a much higher level: generally $60-85 \%$ of the level in unirradiated cells.

The relative DNA synthesis rate in cells of the 3 siblings was clearly elevated and in the range for AT patients.

The increased level of 'radioresistant DNA synthesis' is in accordance with the diagnosis of AT.

\section{Discussion}

In a recent review Sedgwick and Boder [5] outlined the clinical and laboratory parameters of AT. They stated that an early-onset progressive cerebellar ataxia with a later onset of oculocutaneous telangiectasia is an absolute requirement for the diagnosis. They thought it conceivable, however, that telangiectasia might be absent. In the present family the following differences compared with the classical features of AT were observed: telangiectasia ocular or otherwise, even in advanced stages was absent, a severe and progressive distal amyotrophy was a prominent early feature, violent myoclonus in 2 patients was conspicuous, frequent sinopulmonary infections did not occur, there were no signs of either female or male hypogonadism and the 4 patients had a prolonged survival.

During the last decade a few cases of possible AT variants without telangiectasia were reported [12-14]. Telangiectasia is not a feature in the syndrome mimicking AT described by Aicardie et al. [15]. We agree that this syndrome does not represent an AT variant and should rather be classified as a spinocerebellar degeneration without known aetiology.

Recently Willems et al. [16] published a well-docu- mented report of 2 siblings with an atypical presentation of AT involving absence of telangiectasia. Our patients differ from those of these authors in that they were not quadriplegic, had retained tendon reflexes, except at the ankles, showed only mild sensory deficits and had normal ocular fundi, none of them was obese.

Although distal limb wasting is well-known in advanced stages of AT [3,5,17-19], progressive amyotrophy as a prominent symptom in the early stages of this disorder is unusual. In the presumed case of AT reported by Terenty et al. [20] the polyneuropathy appeared late in the second decade and preceded the ataxia, ocular telangiectasia was absent and there was a history of consanguinity. Chromosomal and radiosensitivity studies were lacking. In our opinion there is insufficient evidence to support the diagnosis of an AT variant in this case.

Peripheral neuron degeneration in AT is well described [18,21-23] and documented. Loss of large myelinated fibres in sural nerve biopsies is a frequent finding $[16,21,23]$. Neurogenic muscular atrophy is also regularly reported $[5,18,19]$. Kwast and Ignatowicz [22] suggest that the slowly progressive sensory system degeneration and the neurogenic amyotrophy could be regarded as characteristic features of AT. This seems to be in agreement with the current concept of AT as a multisystem disorder. Peripheral neuron degeneration is undoubtedly present in our patients, convincing evidence of anterior horn cell degeneration, however, could not be shown. The latter is well-known to occur in neuropathological reports [17,24]. Taking into account the long survival of our patients such changes are likely to be present.

Although choreoathetosis is the most frequently reported extrapyramidal feature in AT, myoclonus is well recognized $[1,3,5,18]$. The violent manifestations, seem to be rare, but may occur $[1,5]$. Conspicuous abating after 20 years which was remarkable in our 2 youngest patients has, to our knowledge, not been described. A decrease of dystonia after 5 years was mentioned by Byrne et al. [13]. An explanation for this phenomenon eludes us.

Sinopulmonary infections and immunodeficiency are frequently reported in AT patients but are not invariable $[5,25,26]$. Both cellular and humoral immunity can be affected [4]. No correlation has been demonstrated between isolated and combined immunological defects and sinopulmonary infections $[5,26]$. On the other hand, normal IgA and IgE serum levels have been measured in patients with AT and notable pulmonary symptoms [27]. The increased immunoglobulins reported in our patients may have been related to environmental factors, such as poor living conditions.

Hypogonadism is a prominent feature in AT [5]. Clinical history, gynaecological and ultrasonic investigations in our youngest female patient showed nothing abnormal in this respect. Secondary sexual characteristics in 
the 4 patients, testicular development and sexual maturation in the 2 youngest patients was normal. Detailed endocrinological studies, however, were not performed. It can be concluded that striking congenital sexual abnormalities or hypoplasia were not a feature in our patients.

Diabetes, however, being reported in over $50 \%$ of AT patients in their advanced stages [4,5] could also be shown in our 3 oldest subjects. Prolonged survival in AT patients has been reported $[5,17,19,28,29]$. This is also a conspicuous feature in our patients. Absence of frequent sinopulmonary infections and, except in our oldest patient, also of malignancy are likely to have contributed to this phenomenon. The excellent nursing care provided by their mother must also be taken into account in this respect. It is noteworthy that distal amyotrophy was not a feature in the patients of de Jonge and Tijssen [29], but was prominent in those of Goodman et al. [17]. This may illustrate the variable time of onset and rate of progression of this clinical sign.

Ocular movements, different from other familial cerebellar disorders, as described in the earlier literature [30,31], cannot always be demonstrated. In 2 of our patients violent myoclonic jerks prevented detailed ophthalmological investigations.

Having in common the onset of ataxia as a symptom of a cerebellar disorder, although at different ages during the first decade, there is an obvious diversity in clinical course, pointing to intrafamilial variations in our family.

Raised serum $\alpha$-fetoprotein is still considered a consistent parameter of AT [5,6]. Normal values, however, have been reported [5]. In most cases both $\alpha$-fetoprotein and carcinoembryonic antigen are elevated in AT. The discrepancy between the increased former and the normal latter oncofetal antigen in our patients is noteworthy.

An AT locus (or loci) has been assigned to chromosome 11 q22-23 [32-34]. Complementation studies after mutual fusion of cells from different patients have demonstrated the existence of 4 different AT complementation groups and 2 groups for the related Nijmegen breakage syndrome [35]. Both the clinical and the genetic heterogeneity of AT may suggest that there could be more than one AT gene at this region [33].

Earlier and more recent cytogenetic analysis of AT, as reviewed by Kojis et al. [8] has disclosed high frequencies of characteristic chromosomal rearrangements in this disease, involving mainly specific breakpoints on chromosomes 7 and 14. Translocations and inversions of these chromosomes have also been found in phenotypically normal people, although with significantly lower frequencies, and they are therefore not unique to AT [8]. Chromosomal bands 2 and 22 have also been involved, although to a lesser extent in reciprocal exchanges with one another [8].

The results of chromosomal analysis in the present study are in general agreement with other studies [8]. Radioresistant DNA synthesis is a characteristic feature of AT [9]. Recently, however, Jaspers et al. [35] described variants with a relatively low cellular radiosensitivity and a normal inhibition of DNA synthesis. The very rare Nijmegen Breakage Syndrome, characterized by congenital microcephaly and mental retardation, also exhibits radioresistant DNA synthesis, as well as a high incidence of malignancy and immunodeficiency. It is, however, clinically distinct from AT in that the patients do neither show cerebellar ataxia, and ocular telangiectasia nor increased $\alpha$-fetoprotein serum levels [36].

The data from the 4 siblings of this family suggest that the clinical spectrum of AT may include patients in whom conventional signs and symptoms are absent.

The present report describes a probable rare variant of AT and underlines the importance of special investigations such as cytogenetic analysis and radioresistant DNA synthesis in the diagnostic process and evaluation of this incurable disease.

Both AT and the Nijmegen Breakage Syndrome can be detected in the first trimester of pregnancy [36] which makes adequate diagnostic procedures mandatory in appropriate situations.

\section{Acknowledgements}

We gratefully acknowledge the critical discussions with Dr. E.M. Petersen, Department of Human Genetics, University of Cape Town Medical School, Observatory, 7925, South Africa, and the sophisticated tests performed in the differential diagnosis of AT in her laboratory. We are also indebted to Prof. D.W. Beatty, Department of Paediatrics \& Child Health, Red Cross War Memorial Children's Hospital, Rondebosch, Cape 7700 , South Africa, for the detailed immunological studies performed in his laboratory, to Dr. P.A. Kirby, Department of Anatomical Pathology, Neuropathology Unit, Tygerberg Hospital and University of Stellenbosch Medical School, Parowvallei, and to Mrs. M. van der Kraan and Mr. P. Simons, Rotterdam for performing DNA synthesis studies in cultured fibroblasts.

\section{References}

[1] Boder, E. and Sedgwick, R.P. (1958) Ataxia-telangiectasia, a familial syndrome of progressive cerebellar ataxia, oculocutaneous telangiectasia and frequent pulmonary infection. Pediatrics, 21: 526-554.

[2] Sedgwick, R.P. and Boder, E. (1972) Ataxia-telangiectasia. In: Vinken, P.J. and Bruyn, G.W. (Eds.), Handbook of Clinical Neurology, Vol. 14, North Holland Publ. Comp., Amsterdam, pp. 267-339.

[3] Boder, E. and Sedgwick, R.P. (1963) Ataxia-telangiectasia: a review of 101 cases. In: Walsh, G. (Ed.), Little Club Clinics in Developmental Medicine, No. 8, Cerebellum, posture and cerebral 
palsy, The National Spastics Society and Heinemann Medical Books Ltd., London, pp. 110-118.

[4] Waldmann, T.A., Misiti, J., Nelson, D.L. and Kraemer, K.H. (1983) Ataxia-telangiectasia: a multisystem hereditary disease with immunodeficiency, impaired organ maturation, X-ray hypersensitivity and a high incidence of neoplasia. Ann. Intern. Med., 99: 367-379.

[5] Sedgwick, R.P. and Boder, E. (1992) Ataxia-Telangiectasia (208900; 208910; 208920). In: Vinken, P.J. and Bruyn, G.W. (Eds.), Handbook of Clinical Neurology, Vol. 60, Elsevier Science Publishers, Amsterdam, pp. 347-423.

[6] Waldmann, T.A. and Mclntire, K.R. (1972) Serum alpha-fetoprotein levels in patients with ataxia-telangiectasia. Lancet, 2: 11121115 .

[7] Sugimoto, T., Sawada, T., Tozawa, M., Kidowaki, T., Kusunoki, T. and Yamaguchi, N. (1978) Plasma levels of carcinoembryonic antigen in patients with ataxia-telangiectasia. J. Pediatr., 92: 436439.

[8] Kojis, T.L., Gatti, R.A. and Sparkes, R.S. (1991) The cytogenetics of ataxia-telangiectasia. Cancer Genet. Cytogenet., 56: 143-156.

[9] De Wit, J., Jaspers, N.G.J. and Bootsma, D. (1981) The rate of DNA synthesis in normal human and ataxia-telangiectasia cells after exposure to X-irradiation. Mutat. Res., 80: 221-226.

[10] Jaspers, N.G.J., Taalman, R.D.F.M. and Baan, C. (1988) Patients with an inherited syndrome characterized by immunodeficiency, microcephaly and chromosomal instability: genetic relationship to ataxia-telangiectasia. Am. J. Hum. Genet., 42: 66-73.

[11] Jaspers, N.G.J., de Wit, J., Regulski, M.R. and Bootsma, D. (1982) Abnormal regulation of DNA replication and increased lethality in ataxia telangiectasia cells exposed to carcinogenic agents. Cancer Res., 42: 335-341.

[12] Ying, K.L. and Decoteavi, W.E. (1981) Cytogenetic anomalies in a patient with ataxia, immunodeficiency and a high alpha-fetoprotein in the absence of telangiectasia. Cancer Genet. Cytogenet., 4: 311-317.

[13] Byrne, E., Hallpike, J.F., Manson, J.I., Sutherland, G.R. and Thong, Y.H. (1984) Ataxia without telangiectasia. Progressive multisystem degeneration with IgE deficiency and chromosomal instability. J. Neurol. Sci., 66: 307-317.

[14] Maserati, E., Ottolini, A., Veggiotti, P., Lanzi, G. and Pasquali, F. (1988) Ataxia without telangiectasia in two sisters with rearrangements of chromosomes 7 and 14. Clin. Genet., 34: 283-287.

[15] Aicardi, J., Barbosa, C., A.ndermann, E. et al. (1988) Ataxia-ocular motor apraxia: a syndrome mimicking ataxia-telangiectasia. Ann. Neurol., 24: 497-502.

[16] Willems, P.J., Van Roy, B.C., Kleijer, W.J., Van der Kraan, M and Martin, J.J. (1993) Atypical clinical presentation of ataxiatelangiectasia. Am. J. Med. Genet., 45: 777-782.

[17] Goodman, W.N., Cooper, W.C., Kessler, G.B., Fischer, M.S. and Gardner, M.B. (1969) Ataxia-telangiectasia. Bull. Los Angeles Neurol. Soc., 34: 1-22.

[18] McFarlin, D.E., Strober, W. and Waldmann, T.A. (1972) Ataxiatelangiectasia. Medicine, 51: 281-314.

[19] Amromin, G.D., Boder, E. and Teplitz, R. (1979) Ataxia-telangiectasia with a 32 year survival. J. Neuropathol. Exp. Neurol., 38: 621-643.
[20] Terenty, T., Robson, P. and Walton, J.N. (1979) Presumed ataxiatelangiectasia in a man. Br. Med. J., 2: 802.

[21] Cruz Martinez, A., Barrio, M., Guttierrez, A.M. and López, A (1977) Abnormalities in sensory and mixed evoked potentials in ataxia-telangiectasia. J. Neurol. Neurosurg. Psychiat., 40: 4449.

[22] Kwast, O. and Ignatowicz, R. (1990) Progressive peripheral neuron degeneration in ataxia telangiectasia: an electrophysiological study in children. Dev. Med. Child Neurol., 32: 800-807.

[23] Schaumburg, H.H., Berger, A.R. and Thomas, P.K. (1992) Disorders of peripheral nerves with and without established metabolic basis. In: Schaumburg, H.H., Berger, A.R. and Thomas, P.K. (Eds.), Disorders of Peripheral Nerves, chapter 15, 2nd edn., Davis Comp., Philadelphia, P.A., pp. 203.

[24] Aguilar, M.J., Kamoshita, J., Landing, B.H., Boder, E. and Sedgwick, R.P. (1968) Pathological observations in ataxia-telangiectasia. J. Neuropathol. Exp. Neurol., 27: 659-676.

[25] Ammann, A.J., Cain, W.A., Ishizaka, K., Hong, R. and Good, R.A. (1969) Immunoglobulin $\mathrm{E}$ deficiency in ataxia-telangiectasia. New Engl. J. Med., 281: 469-472.

[26] Polmar, S.H., Waldmann, T.A., Balestra, S.T., Jost, M.C. and Terry, W.D. (1972) Immunoglobulin $E$ in immunologic deficiency diseases. J. Clin. Invest., 51: 326-330.

[27] Jason, J.M. and Gefland, E.W. (1979) Diagnostic considerations in ataxia-telangiectasia. Arch. Dis. Child., 54: 682-686.

[28] Saxon, A., Steven, R.H. and Golde, D.W. (1979) Helper and suppressor T-lymphocyte leukemia in ataxia telangiectasia. New Engl. J. Med., 300: 700-704.

[29] De Jonge, J. and Tijssen, C.C. (1988) Ataxia telangiectasia in a brother and sister at older age. Clin. Neurol. Neurosurg., 90(3): 279-281.

[30] Lawton Smith, J. and Cogan, D.G. (1959) Ataxia-telangiectasia. Arch. Ophthalmol., 62: 364-369.

[31] Baloh, R.W., Yee, R.D. and Boder, E. (1978) Eye movements in ataxia-telangiectasia. Neurology, 28: 1099-1104.

[32] Gatti, R.A., Berkel, I., Boder, E. et al. (1988) Localization of an ataxia-telangiectasia gene to chromosome 11q22-23. Nature, 336: $577-580$.

[33] Foroud, T., Wei, S., Ziv, Y. et al. (1991) Localization of an Ataxiatelangiectasia locus to a 3-cM interval on chromosome 11q23: linkage analysis of 111 families by an international consortium. Am. J. Hum. Genet., 49: 1263-1279.

[34] McConville, C.M., Woods, C.G., Farrall, M., Metcalfe, J.A. and Taylor, A.M.R. (1990) Analysis of 7 polymorphic markers at chromosome 11q22-23 in 35 ataxia-telangiectasia families; further evidence of linkage. Hum. Genet., 85: 215-220.

[35] Jaspers, N.J.G., Gatti, R.A., Baan, C., Linssen, P.C.M.L. and Bootsma, D. (1989) Genetic complementation analysis of ataxiatelangiectasia and Nijmegen breakage syndrome - a survey of 50 patients. Cytogenet. Cell Genet., 49: 259-263.

[36] Jaspers, N.G.J., Van der Kraan, M., Linssen, P.C.M.L., Maçek, M., Seemanová, E. and Kleijer, W.J. (1990) First trimester prenatal diagnosis of the Nijmegen breakage syndrome and ataxia-telangiectasia using an assay of radioresistant DNA synthesis. Prenat. Diagn., 10: 667-674. 